\title{
PENERAPAN PRINSIP SYARIAH PADA LEMBAGA JASA KEUANGAN PERASURANSIAN DI INDONESIA
}

\author{
Renny Supriyatni B. dan Asep Ahmad Fauji \\ Fakultas Hukum \\ Universitas Padjajaran \\ renibachro@ymail.com dan aafauji@gmail.com
}

\begin{abstract}
Abstrak
A kad murabahah merupakan akad yang menerapkan prinsip jual beli. Dalam $\triangle$ perkembangan jaman yang semakin dinamis, akad murabahah mengalami perubahan 1 dalam pelaksanaannya, seperti yang dilakukan oleh PT. Bank Mandiri Syariah akad murabahah digunakan untuk pembiayaan modal usaha sedangkan Asuransi Takaful Keluarga merupakan suatu lembaga yang menjalankan usaha perlindungan yang bersedia mengambil alih risiko atas ancaman bahaya atas kekayaan, badan dan jiwa orang berdasarkan Prinsip Syariah.Dalam hal menghadapi risiko kematian, seseorang mengatasi risiko mengatasi risiko dengan mengalihkannya pada pihak lain dalam hal ini lembaga asuransi jiwa dengan cara mengalihkan risiko menjadi tertanggung pada lembaga asuransi tersebut. Pengaturan perjanjian pengalihan kerugian kepada lembaga asuransi jiwa tersebut dituangkan dalam suatu polis asuransi jiwa. Polis tersebut harus merupakan suatu polis yang mempunyai kekuatan hukum yang mengikat kedua belah pihak yaitu pihak penaggung daan pihak tertanggung. Permasalahannya, bagaimanakah perjanjian pembiayaan Murabahah dengan jaminan polis asuransi jiwa dalam praktik menurut hukum Islam dikaitkan dengan Undang-undang Nomor 40 Tahun 2014 Tentang Perasuransian. Penelitian ini bertujuan, memperoleh gambaran dalam praktik, perjanjian pembiayaan Murabahah dengan jaminan polis asuransi jiwa didasarkan hukum Islam dan Undang-undang Nomor 40 Tahun 2014 Tentang Perasuransian. Penelitian ini bersifat deskriptif analistis yaitu, penelitian yang bertujuan menggambarkan, permasalahan hukum lapangan dalam fakta-fakta berupa data sekunder yang berhubungan dengan permasalahan. Hasil penelitian disimpulkan bahwa, dalam praktik bentuk kerjasama Asuransi Takaful Keluarga Syariah dengan Bank Mandiri Syariah tertuang dalam bentuk perjanjian kerjasama berupa Memorandum of Understanding (MoU) yang didalamnya mengandung akad musytarakah. Salah satu produk Asuransi, dimana Bank Mandiri Syariah sebagai pihak pertama (penyelenggara produk pembiayaan), sedangkan Asuransi Takaful sebagai pihak kedua (atas nama agency Takaful Keluarga). Pengalihan hak jaminan Ahli waris dari Pemegang Polis yang telah meninggal berhak mendapatkan pengalihan hak jaminan Polis Asuransi Jiwa yang dimiliki oleh Pemegang Polis (yang teleh meninggal) dari PT. Asuransi Takaful Keluarga yang dibayarkan melalui PT. Bank Mandiri Syariah karena merupakan hak dari ahli warisnya (subjek dalam asuransi Jiwa).
\end{abstract}

Kata Kunci: Murabahah, Asuransi, Prinsip Syariah, dan Hukum Islam

\begin{abstract}
$B$ asically in the study of Fiqh Muamalat, Akad murabahah is an agreement that applies the principles of buying and selling. In the development of an increasingly dynamic Zaman, murabahah changes in implementation, as was done by PT. Bank Syariah Mandiri murabahah used to finance working capital while Asuransi Takaful Keluarga is an institution that runs safeguards that are willing to take over the risk of danger of wealth, body and soul of people based on Sharia Principles. In terms of the risk of death, a person cope with the risk of dealing with risk divert it to the other parties in this case the life insurance
\end{abstract}


institutions by transferring the risk of being insured at the insurance institute. Loss transfer agreement setting to life insurance agency is outlined in a life insurance policy. The policy must be a policy that has binding legal force both parties that the penaggung passage and insureds. The identification problem in this study, namely how Murabah financing agreement with a guarantee of a life insurance policy in the practice under Islamic law associated with Law Number 40 Year 2014 concerning Insurance. Based on the studies concluded that the Family Takaful Insurance forms of cooperation with Bank Syariah Mandiri Syariah embodied in the form of a cooperation agreement in the form of a Memorandum of Understanding (MoU), which also contains a Musharaka contract. With one insurance product, which Bank Mandiri Syariah as the first party that is the organizer of financing products, while Takaful insurance as the second party in this case acted as aas agency name Family Takaful. The transfer of security rights heirs of a deceased policyholder entitled to a transfer of the rights assurance life insurance policy owned by a policyholder who teleh died from PT. Family Takaful insurance payment by PT. Bank Mandiri Syariah because it is the right of the heirs other than the heirs is subject in life insurance.

Keywords: Murabahah, Insurance, Syariah, Islamic Law

\section{Pendahuluan}

Perusahaan asuransi berdiri dan melakukan usahanya dalam rangka memenuhi kebutuhan manusia untuk mendapat perlindungan terhadap risiko yang mungkin terjadi. Pihak yang menanggung risiko yang mungkin terjadi, merupakan pihak yang telah mengalihkan risiko kepada pihak lain dengan kesanggupan membayar kontrak prestasi yang disebut premi. ${ }^{67}$ Tertanggung dengan membayar sejumlah premi kepada perusahaan asuransi (penanggung) sejak itu pula risiko beralih kepada penanggung terlepas apakah risiko itu terjadi atau tidak. Pihak perusahaan asuransi (penanggung) dan tertanggung, sama-sama memiliki hak dan kewajiban atas syarat-syarat yang sudah disepakati bersama dalam suatu polis. Antara penanggung dan tertanggung telah terjadi hubungan hukum yang harus dilandasi oleh suatu perjanjian yang disebut perjanjian pertanggungan atau perjanjian asuransi. ${ }^{68}$

Kerja sama antara perusahaan asuransi dengan pengguna jasa asuransi maka terbit suatu hubungan hukum, kemudian dituangkan dalam suatu perjanjian terulis yang memberlakukaan ketentuan-ketentuan dan syarat-syarat yang jelas antara para pihak dalam perjanjian. Dikemukakan oleh Mariam Darus Badrulzaman bahwa pada dasarnya Kitab Undang-undang Hukum Perdata (selanjutnya ditulis KUHPerdata) mengandung asas keseimbangan melalui ketentuan Pasal 1338 ayat (3) KUHPerdata yang mempersyaratkan suatu perjanjian harus dilaksanakan para pihak dengan itikad baik sejak perjanjian diberlakukan dan selama masa perjanjian berlangsung. ${ }^{69}$

Perkembangan usaha perasuransian mengikuti perkembangan ekonomi masyarakat. Kegiatan usaha asuransi kini makin berkembang yang membawa konsekuensi berkembang pula hukum bisnis asuransi. Salah satu kegiatan bisnis asuransi yang muncul dalam masyarakat adalah bisnis asuransi syariah, sebagaimana tertuang dalam Pasal 1 angka (2) Undang-Undang Nomor 40 Tahun 2014 Tentang Perasuransian (selanjutnya ditulis UUP) yang memberikan penjelasan bahwa :

"Asuransi Syariah merupakan kumpulan perjanjian, yang terdiri atas perjanjian antara perusahaan asuransi syariah dan pemegang polis dan perjanjian diantara para pemegang polis, dalam rangka pengelolaan kontribusi berdasarkan prisnsip syariah guna saling menolong dan melindungi dengan cara:

67 Abdulkadir Muhammad, Hukum Asuransi Indonesia, PT Citra Aditya Bakti, Bandung, 2002, hllm 118.

68 Djoko Prakoso dan I Ketut Murtika, Hukum Asuransi Indonesia, Rineka Cipta, Jakarta, 1994, hlm 16 - 17.

69 Mariam Darus Badrulzaman, Aneka Hukum Bisnis, Allumni, Bandung, 2005, hlm 43 
Memberikan penggantian kepada peserta atau pemegang polis karena kerugian, kerusakan, biaya yang timbul, kehilangan keuntungan, atau tanggung jawab hukum kepada pihak ketiga yang mungkin diderita peserta atau pemegang polis karena terjadinya suatau peristiwa yang tidak pasti atau

Memberikan pembayaran yang didasarkan pada meninggalnya peserta atau pembayaran yang didasarkan pada hidupnya peserta dengan manfaat yang besarnya telah ditetapkan dan / atau didasarkan pada hasil pengelolaan dana.

Seiring berkembangnya ekonomi syariah di Indonesia dan mayoritas penduduk Indonesia beragama Islam, maka kebutuhan akan asuransi yang berdasarkan hukum syariah sangat diperlukan. Asuransi syariah merupakan bidang bisnis asuransi yang cukup memperoleh perhatian besar dikalangan masyarakat Indonesia. Asuransi syariah sebagai bisnis asuransi alternatif, pengoperasian kegiatannya berdasarkan alquran dan hadist serta fatwa para ulama yang tergabung dalam Majelis Ulama Indonesia (selanjutnya ditulis MUI).Asuransi yang menerapkan prinsip-prinsip syariah harus sesuai dengan Pasal 3 UUP, pada dasarnya mengarah kepada pembangunan masyarakat untuk saling kerja sama, saling membantu, saling bertanggung jawab dan saling melindungi penderitaan satu sama lain. ${ }^{70}$

Asuransi Konvensional sebenanya juga mengenal Prinsip Gotong Royong, yang dimaksud dalam hal ini adalah Prinsip yang mendasarkan kepada penyelesaian terhadap suatu masalah dengan saling tolong menolong. ${ }^{71}$ Pada prinsipnya tersebut hampir sama dengan asas tolong menolong yang dianut dalam asuransi syariah, namun karena penduduk Indonesia yang mayoritas beragama Islam masih beranggapan bahwa asuransi konvensional tidak sesuai dengan prinsip syariah karena mengandung unsur ketidakpastian (gharar), perjudian (Maysir) dan bunga (riba). Prinsip-prinsip dasar di dalam syariah mengajak kepada manusia untuk membina persaudaraan dan membantu meringankan masalah ataupun bencana yang sedang dihadapi sesamanya. Hal ini sesuai dengan firman Allah yang terdapat dalam QS. Al - Maidah ayat 2 yang artinya:

“... dan tolong menolonglah kamu dalam ( mengerjakan) kebajikan dan takwa, dan jangan tolong menolong dalam berbuat dosa dan pelanggaran. Dan bertakwalah kamu kepada Allah, sesungguhnya Allah amat berat Siksanya"

Berdasarkan latar belakang yang telah duraikan, permasalahan yang dihadapi, bagaimanakah perjanjian pembiayaan Murabahah dengan jaminan polis asuransi jiwa dalam praktik menurut Hukum Islam dikaitkan dengan Undang-undang Nomor 40 Tahun 2014 Tentang Bisnis asuransi?

\section{Pembahasan}

\section{Perjanjian Asuransi Syariah}

Perjanjian atau akad menurut Hukum Islam, terdapat dalam Al- Qur'an dua istilah yang berhubungan dengan perjanjian, yaitu al-'aqdu (akad) dan al-'ahdu, sebagai berikut:

a. QS. Al - maidah : 1, yang artinya bahwa manusia diminta untuk memenuhi akadnya, dimana istilah al-'aqdu dapat disamakan dengan istilah verbintenis (perikatan) dalam KUHPerdata. ${ }^{72}$

b. QS. Ali Imran : 76yang artinya, dimana istilah al-‘ahdu dapat disamakan dengan istilah overeenskomst (perjanjian).

Pengertian akad menurut para ahli hukum islam adalah perikatan anatara ijab (penawaran) dan kabul(penerimaan) yang di benarkan oleh syara'(hukum islam). Abdoerraoefmengemukakan terjadinya suatu perikatan (al-'aqdu) melalui tiga tahap, yaitu : $:^{73}$

70 Sri Redjeki Hartono, Hukum Asuransi dan Perusahaan Asuransi, Sinar Grafika, Jakarta, 1997, hlm. 2.

71 Man Suparman Sastrawidjaja, Aspek - aspek Hukum Asuransi dan Surat Berharga, PT. Alumni, Bandung, 2003, hlm. 79.

72 Gemala Dewi, Hukum Perikatan Islam di Indonesia, Jakarta, Kencana, 2005, hlm. 45.

73 Gemala Dewi, Ibid, hlm. 46. 
a. Al-'ahdu (perjanjian), yaitu pernyataan dari seorang untuk melakukan sesuatu atau tidak melakukan sesuatu dan tidak ada hubungannya dengan kemauan orang lain.

b. Persetujuan, yaitu pernyataan setuju dari pihak kedua untuk melakukan sesuatu atau tidak melakukan sesuatu sebagai reaksi terhadap janji yang dinyatakan oleh pihak pertama, dimana persetujuan tersebut harus sesuai dengan janjian pihak pertama.

c. Apabila dua buah janji dilaksanakan maksudnya oleh para pihak, maka terjadilah apa yang dinamakan 'aqdu. Maka yang mengikat masing-masing pihak sesudah pelaksanaan perjanjian bukan lagi ahdu atau perjanjian, teapi, aqdu (perikatan).

Proses perikatan tersebut, tidak terlalu berbeda dengan proses perikatan yang didasarkan pada KUHPerdata. Begitu pula peristiwa perjanjian, menimbulkan hubungan diantara orang orang tersebut yang disebut dengan perikatan. Dengan demikian, hubungan antara perikatan dengan perjanjian adalah perjanjian menerbitkan perikatan, sebagaimana tercantum dalam Pasal 1233 KUHPerdata, bahwa perjanjian merupakan salah satu sumber perikatan.

Syarat sahnya perjanjian (Akad), sebagai berikut:

a. Subjek perikatan (al-aqidain)

Dalam KUHPerdata bahwa Subjek Hukum dalam Islam memiliki kesamaan yakni Manusia yang sudah dapat dibebani hukum dan Badan Hukum yang merupakan suatu persekutuan (syirkah) yang dapat bertindak dalam hukum dan mempunyai hak, kewajiban serta dapat melakukan hubungan hukum terhadap orang lain atau badan hukum namun Kecakapan hukum menurut prinsip syariah Islam, bahwa tidak semua orang dapat melaksanakan sendiri hak dan kewajibannya yang diistilahkan dengan kecakapan hukum menurut prinsip syariah Islam. Menurut pendapat para ahli, orang yang tidak cakap bertindak adalah: ${ }^{74}$

1) Anak yang masih dibawah umur (Q.S. An Nissa:6)

2) Orang yang tidak sehat akal (Q.S. Al-Baqarah:282)

3) Orang yang boros (pendapat Imam Syafi'i)

Perbedaan antara hukum perjanjian perdata dengan prinsip syariah Islam hanya terlihat dalam pengaturan mengenai batas usia dewasa. Menurut hukum perjanjian perdata, dewasa menurut pasal 330 KUHPerdata adalah apabila genap berusia 21 tahun atau telah kawin. Sedangkan menurut prinsip syariah, batas usia dewasa dikatakan oleh Imam Syafi'i bahwa harus sudah berumur 15 tahun bagi laki - laki atau apabila sudah mimpi bersetubuh dan untuk perempuan apabila sudah berumur 15 tahun atau sudah haid.

b. Objek perikatan (mahallul 'aqd)

Mahallul'aqd adalah sesuatu yang dijadikan objek akad dan dikarenakan padanya akibat hukum yang ditimbulkan. Bentuk objek akad dapat berupa benda berwujud maupun benda tak terwujud, seperti manfaat. Syarat - syarat objek akad yaitu: ${ }^{75}$

1) Objek perikatan telah ada ketika akad dilangsungkan

2) Objek perikatan dibenarkan oleh syariah

3) Objek akad harus jelas dan dikenali

4) Objek dapat diserah terimakan

c. Tujuan perikatan (maudhu'u al-'aqdi)

Maudhu'u al-'aqdi ialah tujuan akad atau maksud pokok mengadakan akad atau dalam KUHPerdata hal ini merupakan suatu "prestasi" (hal yang dituntut oleh satu pihak kepada pihak lainnya), yang dirumuskan dengan menyerahkan barang, melakukan sesuatu atau tidak melakukan sesuatu. ${ }^{76}$ Syarat - syarat dari tujuan akad, yaitu:

74 Chairuman Pasaribu dan Suhrawardi K.Lubis, Hukum Perjanjiian dalam Islam, Sinar Grafika, Jakarta, 1994, Hlm. 8-12

75 Op.Cit, Gemala Dewi, Opcit, Hlm. 60-62

76 Ibid, Gemala Dewi, Hlm. 17-18 
1) Baru ada pada saat dilaksanakan akad

2) Berlangsung adanya hingga berakhirnya akad

3) Tujuan akad harus dibenarkan syara.

d. Ijab dan qabul (sighat al-aqd)

Sighat al-aqd adalah suatu ungkapan para pihak yang melakukan akad, berupa ijab dan qabul. Ijab adalah suatu pernyataan janji atau penawaran dari pihak pertama untuk melakukan atau tidak melakukan sesuatu. ${ }^{77}$ Qabul adalah suatu pernyataan menerima dari pihak pertama. 3 (tiga) syarat dalam melakukan ijab dan qabul, antara lain:

1) Jala'ul ma'na, yaitu tujuan yang terkandung dalam pernyataan itu jelas, sehingga dapat dipahami jenis akad yang dikehendaki.

2) Tawafuq, yaitu adanya kesesuaian antara ijab dan qabul.

3) Jamzul iradataini, yaitu antara ijab dan qabul menunjukan kehendak para pihak secara pasti, tidak ragu dan tidak terpaksa.

e. Asas - asas Perjanjian

Berkaitan dengan hukum perikatan Islam, ada tujuh asas yang mendasarinya, yaitu: ${ }^{78}$

1) Asas Ilahiyah

Setiap tingkah laku dan perbuatan manusia tidak akan luput dari ketentuan Allah SWT. Seperti yang disebutkan dalam QS. Al- Hadid (57): 4, bahwa “ Dia bersama kamu dimana saja kamu berada. Dan Allah maha melihat apa yang kamu kerjakan." Kegiatan muamalat termasuk perbuatan perikatan, tidak akan pernah lepas nilai-nilai ketauhidan. Dengan demkian manusia memiliki tanggung jawab kepada diri sendiri dan tanggung jawab kepada Allah SWT. Akibatnya manusia tidak akan berbuat sekehendak hatinya, karena perbuatannya akan mendapat balasan dari Allah SWT.

2) Asas kebebasan (al-hurriyah)

Islam memberikan kebebasan kepada para pihak untuk melakukan suatu perikatan. Bentuk dan isi perikatan tersebut ditentukan oleh para pihak. Apabila telah disepakati bentuk dan isinya, maka perikatan itu mengikat para pihak yang menyepakatinya dan harus dilaksanakan segala hak dan kewajibannya. namun, kebebasan ini tidaklah absolut. Sepanjang tidak bertentangan dengan syariah Islam, maka perikatan tersebut boleh dilasanakan.

3) Asas persamaan atau kesetaraan (al-musawah)

Suatu perbuatan muamalah merupakan salah satu jalan untuk memenuhi kehidupan hidup manusia. Sering kali terjadi, bahwa seseorang memilki kelebihan dan yang lainnya. Seperti yang tercantum dalam QS. An-Nahl (16): 71, bahwa " dan Allah melebihkan sebagian kamu dan sebagian yang lain dalam hal rezeki." Hal ini menunjukan, bahwa di antara sesama manusia masing - masing memiliki kelebihan dan kekurangan. Untuk itu, antara manusia satu dengan yang lain hendaknya saling melengkapi atas kekurangan yang lain dan kelebihan yang dimilikinya. Oleh karena itu, setiap manusia memiliki kesempatan yang sama untuk melakukan suatu perikatan.

4) Asas keadilan (al-adalah)

Adil adalah merupakan salah satu sifat Allah SWT. Yang sering kali disebutkan dalam Al-Qur'an. Bersikap adil sering kali Allah SWT. Tekankan kepada manusia dalam melakukan perbuatan, karena adil menjadikan manusia lebih dekat kepada taqwa. Dalam QS. Al-A'raaf (7) : 29, disebutkan bahwa " katakanlah : "Tuhanku menyuruh supaya berlaku adil". 
5) Asas kerelaan (al-ridho)

Segala transaksi yang dilakukan harus atas dasar suka sama suka atau kerelaan antara masing - masing pihak, tidak boleh ada tekanan, paksaan, penipuan, dan mis-statement. Jika hal ini tidak terpenuhi, maka transaksi tersebut dilakukan dengan cara yang bathil (al-akl bil bathil). Berikut isi dari QS. An-Nisa (4) : 29, " Hai orang - orang yang beriman, janganlah kamu saling memakan harta sesamamu dengan jalan yang bathil, kecuali dengan jalan perniagaan yang berlaku dengan suka sama suka diantara kamu."

6) Asas kejujuran dan kebenaran (ash- shidq)

Kejujuran merupakan hal yang harus dilakukan oleh manusia dalam segala bidang kehidupan, termasuk dalam pelaksanaan muamalat. Jika kejujuran ini tidak diterapkan dalam peikatan, maka akan merusak legalitas perikatan itu sendiri. Selain itu, jika terdapat ketidak jujuran dalam perikatan, akan menimbulkan perselisihan di antara para pihak, dalam QS. Al-Ahzab (33) : 70, disebutkan bahwa "Hai orang-orang yang beriman, bertaqwalah kamu kepada Allah, dan katakanlah perkataan yang benar"

7) Asas - asas tertulis (al-kitabah)

QS. Al-Baqarah (2) : 282-283, disebutkan bahwa Allah SWT menganjurkan kepada manusia hendaknya suatu perikatan dilakukan secara tertulis, dihadiri oleh saksi-saksi dan diberikan tanggung jawab individu yang melakukan perikatan, dan yang menjadi saksi. Selain itu dianjurkan pula bahwa apabila perikatan dilaksanakan tidak secara tunai, maka dapat dipegang suatu benda sebagai jaminannya, adanya tulisan, saksi dan atau benda jaminan ini menjadi alat bukti atas terjadinya perikatan tersebut.

Kebiasaan asuransi, telah diketahui sebelum zaman nabi Muhammad SAW. Pada saat itu terdapat kebiasaan dari bangsa Arab yang bernama aqilah, yaitu apabila seorang anggota suku terbunuh dari anggotanya suku lainnya, maka ahli waris dari korban akan dibayar dengan sejumlah uang sebagai kompensasi yang berasal dari keluarga dekat pembunuh. Keluarga dekat dari pembunuh tersebut (disebut juga aqilah) harus membayar uang sebagai pengganti darah atas nama sang pembunuh. Oleh karena ide dari aqilah ini,yaitu masyarakat Arab terdahulu harus bersiap, untuk memberikan kontribusi finansial atas nama sang pembunuh sebagai kompensasi keturunan dari sang korban. Kesiapan untuk memberikan kontribusi keuangan tersebut, menyerupai premi yang dibayar pada praktik asuransi masa kini, dimana kompensasi yang di bayar di al-aqilah dapat menyerupai ganti rugi pada asuransi masa kini, karena merupakan jenis perlindungan keuangan untuk ahli waris dari sang korban yang kematiannya tidak dapat terduga sebelumnya. ${ }^{79}$

Selain al-aqilah, konsep-konsep Islam lama lainnya yang mengarah pada konsep asuransi adalah al-muawalat (perjanjian jaminan dalam hal penjamin menjamin seorang yang tidak memiiki waris dan tidak dikeetahui ahli warisnya), al-qasamah (usaha pengumpulan dana dalam sebuah tabungan atau pengumpulan uang iuran dari peserta atau majelis, manfaatnya akan dibayarkan kepada ahli waris korban yang dibunuh jika kasus pembunuhannya tidak diketahui siapa pelakunya), at-tanahud (praktek kebiasaan mengumpulkan makanan dari para peserta safar kemudian dicampur jadi satu dan kemudian dibagikan pada saatnya kepada mereka secara merata), aqad al-hirasah (kontrak pengawal keselamatan), dhiman khatr tariq (kontrak jaminan keselamatan lalu lintas), al-wadi'ah biurin (kontrak penitipan yang menyatakan apabila terjadi kerusakan pada barang ketika dikembalikan, maka pihak penerima penitipan wajib menggantinya), dan nizam at-taqaud (sistem pensiun). ${ }^{80}$

79 Op.Cit, Zainudin Ali, Hlm 10-11.

80 Muhammad Syakir Sula, Asuransi Syariah (life and General) Gema Insani, Jakarta, 2004, Hlm 82-84. 
Kebiasaan itu terus berkembang sesuai zamannya hingga pada abad ke-19, ibn'Abidin mengusulkan adanya pendirian asuransi sebagai suatu institusi yang memiliki dasar hukum. Muhammad Abdul yang kemudian pada abad ke-20 mengeluarkan dua fatwa diantara tahun 1900-1901 yang melegalisasikan kebiasaan asuransi. Pada tahun 1979 didirikanlah perubahan asuransi syariah yang bernama Islamic Insurance Company of Sudan. Berdeda dengan asuransi konvensional, asuransi Islam beroperasi sesuai dengan prinsip syariat dengan cara menghilangkan sama sekali kemungkinan terjadiya unsur - unsur gharar, maisir, dan riba. Bentuk - bentuk usaha dan investasi yang dibenarkan syariat Islam adalah yang lebih menekankan kepada keadilan dengan mengharamkan riba dan dengan mengembangkan kebersamaan dalam menghadapi risiko usaha. ${ }^{81}$

\section{Dasar Hukum Asuransi Syariah}

Pasal 20 angka (26) Kompilasi Hukum Ekonomi Syariah, pengertian ta'min/asuransi adalah perjanjian antara dua pihak atau lebih, pihak penanggung mengikatkan diri kepada tertanggung dengan menerima premi ta'min untuk menerima penggantian kepada tertanggung karena kerugian, kerusakan, atau kehilangan keuntungan yang diharapkan, atau tanggung jawab hukum kepada pihak ketiga yang mungkin akan diderita tertanggung yang timbul dari peristiwa yang tidak pasti.Asuransi disebut dalam bahasa arab dengan at-ta'min, sedangkan penaggung disebut mu'ammin, sedangkan peserta disebut mua'mman lahu atau musta'min. Men-ta'min- kan sesuatu artinya adalah seseorang membayar/menyerahkan uang cicilan agar ia atau ahli warisnya mendapatkan sejumlah uang sebagaimana yang telah disepakati, atau untuk mendapatkan ganti terhadap hartanya yang hilang. ${ }^{82}$

Asuransi Syariah mempunyai beberapa pandanan dalam bahasa arab, diantaranya, yaitu, takaful, ta'min dan tadhamun. Ketiga kata tersebut merupakan padanan dari pengertian asuransi syariah, yang mempunyai makna saling menanggung, memberi rasa aman dan saling menolong. Definisi dari asuransi syariah menurut Ketentuan Umum Fatwa Dewan Syariah Nasional (DSN) No. 21/DSN-MUI/X/2001 Tentang Pedoman umum Asuransi Syariah, yaitu asuansi syariah (ta'min, takaful, tadhamun) adalah usaha saling melindungi dan tolong-menolong diantara sejumlah orang/pihak melalui investasi dalam bentuk asset atau tabarru yang memberikan pola pengembalian untuk menghadapi resiko tertentu melalui akad (perikatan) yang sesuai dengan syariah.Berdasarkan definisi tersebut tampak bahwa asuransi syariah bersifat saling melindungi dan tolong menolong yang disebut dengan "ta'awun, yaitu prinsip hidup saling melindungi dan saling menolong atas dasar ukhuwah islamiah antara sesama anggota peserta asuransi syariah dalam menghadapi malapetaka (risiko). Oleh sebab itu, premi pada asuransi syariah adalah sejumlah dana yang dibayarkan oleh peserta yang terdiri atas dana tabungan dan dana tabarru.

Dana Tabungan adalah dana titipan dari peserta asuransi syariah dan akan mendapat alokasi bagi hasil (al-mudharabah) dari pendapatan investasi bersih yang diperoleh setiap tahun. Dana tabungan beserta alokasi bagi hasil akan dikembalikan kepada peserta apabila peserta yang bersangkutan mengajukan klaim, baik yang berupa klaim tunai maupun klaim manfaat asuransi. Sedangkan, tabarru adalah derma atau dana kebajikan yang diberikan dan di ikhlaskan oleh peserta asuransi jika sewaktu-waktu akan dipergunakan untuk membayar klaim atau manfaat asuransi (life maupun general insurance). ${ }^{83}$

\section{Pembahasan}

Kerjasama Asuransi Takaful Keluarga dengan Bank Mandiri Syariah meliputi dua aspek, aspek Perbankan Syariah dan Perbankan Konvensional, aspek pertama untuk Perbankan Syariah yaitu:

81 Wirdyaningsih, Bank dan Asuransi Islam di Indonesia, Kencana, Jakarta, 2005, Hlm 207.

82 Op.Cit, Muhammad Syakir Sula, Hlm 82.

83 Ibid, Muhammad Syakir Sula, Hlm. 30. 
a. Pembayaran premi pertama dan lanjutan.

b. Kolaborasi produk

1) Dana pensiun Lembaga Kerja (DPLK)

2) Tabungan Arafah.

3) Pembiayaan

Untuk pembayaran premi kepada Takaful Keluarga melalui Bank Syariah memiliki cara yang sedikit berbeda, contohnya pada Bank Mandiri Syariah, setiap melakukan pembayaran premi pertama ataupun premi lanjutan harus menggunakan sandi atau pin dengan menyebutkan kode: 8987 setelah itu barulah nasabah menyebutkan nomor polis yang telah di tuliskan didalam perjanjian dengan Takaful Keluarga tersebut. Sedangkan terhadap Bank Syariah yang lainnya menyebutkan nomor polis nasabah saja tidak perlu menggunakan kode seperti yang terdapat pada Bank Mandiri Syariah.

Kerjasama ini bisa disebut sebagai cobranding, dimana kerjasama berupa cobranding ini juga dilakukan di PT. Takaful Indonesia yang berkedudukan di kantor pusat. Contoh kerjasama cobranding antara PT. Takaful Indonesia dengan Bank Mandiri Syariah dalam penyelenggaraan pemasaran produk asuransi fulprotek (kartu investasi berabsuransi) dan sekaligus memberikan proteksi kepada nasabah Bank Mandiri Syariah yaitu seorang peserta akan berkedudukan sebagai nasabah Bank Mandiri Syariah sekaligus mendapat perlindungan dari PT. Takaful Indonesia apabila mengikuti Asuransi fulprotek melalui Bank Mandiri Syariah. Paket fulprotek yang ditawarkan yaitu paket 175 , paket 275 , paket 750 dengan prinsip wakalah bil ujarah.

Contoh tersebut di atas, apabila seorang peserta mengambil paket 175 maka peserta tersebut membuka tabungan pada Bank Mumalat sebesar Rp. 175.000,00 dimana Rp. 100.000,00 untuk saldo awal tabungan dan 75.000,00 untuk Asuransi fullprotek dan dari Rp. 75.000,00 nanti akan dibagi untuk Asuransi sebesar Rp. 50.500,00 dan untuk ujrah Bank Mandiri Syariah sebesar Rp. 24.500,00. Kerjasama ini juga dilakukan dengan kantor pos Indonesia sebagai tempat pembayaran premi dari para peserta PT. Takaful Indonesia.

Sedangkan untuk pelaksanaan pada Bank Konvensional hanya ada tiga hubungan kerja, yaitu:

a. Bank Negara Indonesia (BNI)

b. Bank Rakyat Indonesia (BRI)

c. Bank Mandiri

Ketiga bank tersebut hanya sebagai fasilitator untuk para nasabah menyetorkan uang mereka agar lebih memudahkan para nasabah melakukan pembayaran premi Asuransi mereka. Sedangkan untuk keuntungan pada pihak Perbankannya dinamakan Remunerasi (Manajemen Fee). Jadi sesama pihak PT. Asuransi Takaful Keluarga dengan pihak Perbankan Syariah dan Perbankan Konvensional sama-sama diuntungkan, terlebih kepada pihak Perbankan Syariah yang merupakan setiap awal pembukaan polis Asuransi Takaful Keluarga itu, untuk menjadi seorang calon nasabah harus melalui pihak perbankan syariah dahulu melalui pembayaran premi pertama ataupun premi lanjutan.

Dalam praktik pelaksanaannya, Takaful berbeda dengan Asuransi Konvensional. Dalam Takaful setiap nasabah menanggung satunsama lain, maka disinilah praktik tabarru takaful itu terlihat. Oleh karena masing-masing nasabah mengeluarkan dana hibah, untuk nasabah yang lain. Takaful sendiri yang menghimpun dana tersebut, kemudian menyalurkannya. Sebagian digunakan untuk operasional takaful, sebagian diajukan untuk investasi dan sebagian lain adalah dana hibah nasabah. Sehingga akad yang terjadi antara Takaful dan nasabah (kumpulan orang) adalah akad tijarah (komersil) tapi sebagian ladi adalah tabarru. Akad tijarahnya dapat berupa wakalah bil ujarah, mudharabah, atau ijarah. Sehingga Takaful sendiri tidak diperkenankan 
menggunakan dana hibahnya, Tafakul hanya mendapatkan ujrah (upah) yang sebelumnya telah disepakati dengan nasabah (pada umumnya 30\% dari polis asuransi).

Selain berinteraksi dengan nasabah, tafakul juga berinteraksi dengan bank syariah, terjadi mudharabah yang pararel dalam asuransi syariah. Nasabah sebagai shahih al maal, dan asuransi sebagai mudharibnya. Kemudian dana yang dipegang oleh asuransi diberikan kepada bank sebagai mudharib, untuk digunakan usaha yang hasilnya nanti akan dibagikan dengan asas profit-losssharing. Semua akad yang ada di takaful jelas statusnya dan telah diketahui kemana dana tersebut mengalir. Asuransi konvensional yang memanfaatkan bunga bank, berbeda dalam praktiknya. Takaful lebih aman dan terlindung dari magrib (maisir, gharar, riba).

Setiap premi yang dibayarkan oleh nasabah kemudian di alokasikan ke dalam:

a. Rekening tabungan, yaitu rekening yang di alokasikan untuk investasi mudharabah, tabungan investasi mudharabah ini umumnya menghasilkan keuntungan, sehingga dapat memberikan bagi hasil peserta.

b. Rekening tabarru, yaitu rekening yang berfungsi sebagai derma peserta untuk menolong peserta lain yang mengalami musibah atau kecelakaan. Dana tabarru inilah yang dinamakan klaim atas kerugian yang dialami masing-masing peserta. Masing-masing rekening ini lalu dikolektifkan dalam pos keuangan tersendiri, sehingga tidak terjadi percampuran. Dengan ini, maka dana investasi akan masuk kedalam proyek-proyek usaha komersil. Sehingga 70\% dana tersebut dikembalikan kepada nasabah yang bersangkutan, sedangkan 30\% untuk perusahaan Asuransi. Dana tabarru sendiri akan diterima peserta sebagai klaim atas kerugian yang dialami. Sedangkan dana tabarru tidak dikembalikan sampai ketentuan yang telah disepakati, seperti pertanggungan untuk keluarga yang ditinggal meninggal dunia, atau jika rumah nasabah kebakaran.

Pada Asuransi Syariah seluruh aktivitas kegitan diawasi oleh Dewan Pengawas Syariah (DPS) yang merupakan bagian dari Dewan Syariah Nasional (DSN), baik dari segi investasi maupun Sumber Daya Insani/Islami (SDI). Kedudukan DPS dalam struktur organisasi perusahaan setara dengan Dewan Komisaris.Dewan Pengawas Syariah (DPS) sangat berperan dalam mengawasi investasi maupun produk-produk yang berada pada Asuransi Syariah, seperti halnya Produk Takafulink Keluarga. salah satunya Asuransi Syariah di Jakarta Pusat ini, tidak terlepas dari Dewan PengawasSyariah (DPS).Sedangkan pelaksanaan kerjasama PT. Takaful Keluarga Cabang Jakarta Pusat dengan Bank Mandiri Syariah ada tiga yang mendasarinya, yaitu:

a. Pembayaran premi pertama dan lanjutan

b. Kolaborasi produk;

1) Dana pensiun lembaga kerja (DPLK)

2) Tabungan Arafah

c. Pembiayaan

Di dalam melakukan pembayaran tersebut di atas, terkadang ada sedikit kendala dalam pelaksanaan pembayarannya, seperti gangguan eksternal. Gangguan eksternal yaitu gangguan jaringan online dari pihak perbankan, yang menyebabkan keterlambatan pengiriman uang premi ke kantor pusat. Selain itu adanya kesalahan penulisan nomor polis dari pemegang polis dalam melakukan setiap pembayaran premi awal maupun premi lanjutan.namun kendala tersebut tidak begitu menjadi permasalahan besar oleh pihak Takaful Keluarga, karena masih bisa diatasi dan gangguan jaringan online itu pun tidak berlangsung lama ataupun berhari-hari. Kerjasama Asuransi Takaful Keluarga dengan Bank Syariah, dilakukan dengan akadmudharabah yang parerel dalam asuransi syariah.

Nasabah sebagai shahihalmaal, dan asuransi sebagai mudharibnya, kemudian dana yang di pegang oleh asuransi di berikan kepada bank sebagai mudharibnya untuk digunakan usaha. 
Kemudian hasilnya akan dibandingkan dengan asas profit-losssharing. Jadi semua akad yang ada di takaful jelas statusnya dan telah diketahui kemana dana tersebut mengalir.Dalam Takaful Keluarga dapat dikatakan lebih aman dan terlindung mekanismenya dari magrib (maisir, gharar, riba). Karena setiap premi yang dibayarkan oleh nasabah kemudian di alokasikan ke dalam:

a. Rekening tabungan, yaitu rekening yang di alokasikan untuk investasi mudharabah, tabungan investasi mudharabah ini umumnya menghasilkan keuntungan, sehingga dapat memberikan bagi hasil peserta.

b. Rekening tabarru, yaitu rekening yang berfungsi sebagai derma peserta untuk menolong peserta lain yang mengalami musibah atau kecelakaan. Dana tabarru inilah yang dinamakan klaim atas kerugian yang dialami masing - masing peserta.

Selanjutnya kerjasama antara Asuransi Takaful Keluarga dengan Bank Syariah dan Bank Konvensional dalam pembayaran polis Asuaransi dengan cara Bank Syariah membentuk kerjasama seperti kolaborasi produk dan pembiayaan yang tertuang dalam Memorandum of Understanding (MoU). Sedangkan pada Bank Konvensional juga terdapat Memorandum of Understanding (MoU), yang ditekankan dalam bentuk pembayaran saja. Bank Konvensional disini hanya sebagai fasilitator, untuk para nasabah menyetorkan uang mereka. Hal tersebut agar lebih memudahkan para nasabah, melakukan pembayaran premi asuransi mereka, baik itu sebagai pembayaran premi awal mereka atau premi lanjutan.

\section{Penutup}

Dalam praktiknya diperoleh gambaran bahwa, bentuk kerjasama dengan Bank Konvensional dalam pembayaran polis Asuransi adalah kerjasama Asuransi Takaful Keluarga dengan Bank Mandiri Syariah tertuang dalam bentuk perjanjian kerjasama berupa Memorandum of Understanding (MoU) yang didalamnya mengandung akad musyarakah. Salah satu produk Asuransi, di Bank Mandiri Syariah, sebagai pihak pertama yaitu penyelenggara produk pembiayaan, sedangkan Asuransi Takaful sebagai pihak kedua dalam hal ini bertindak sebagai atas nama agency Takaful Keluarga. Para Nasabah yang mayoritas masyarakat kota ini banyak menggunakan jasa perbankan konvensional sebagai tempat menyimpan uang mereka, bahkan sistem pembayaran gaji dan mendepositokannnyasebagai bentuk investasi, tidak melalui Bank Syariah. Bank Syariah hanyapengalihan hak jaminan Ahli waris dari Pemegang Polis Asuransi Jiwa yang telah meninggal yang dimiliki oleh Pemegang Polis, (yang telah meninggal) dari PT. Asuransi Takaful Keluarga yang dibayarkan melalui PT. Bank Mandiri Syariah karena merupakan hak dari ahli warisnya (sebagai subyek asuransi jiwa).

Saran yang diberikan, melakukan sosialisasi Asuransi melalui Bank Syariah secara terus menerus, berkala dan efisien. Selain itu meningkatkan kualitas Sumber Daya Insani/Islami perbankan syariah secara menyeluruh.

\section{Daftar Pustaka}

Abdulkadir Muhammad, Hukum Asuransi Indonesia, PT Citra Aditya Bakti, Bandung, 2002.

Chairuman Pasaribu dan Suhrawardi K.Lubis, Hukum Perjanjiian dalam Islam, Sinar Grafika, Jakarta, 1994.

Djoko Prakoso dan I Ketut Murtika, Hukum Asuransi Indonesia, Rineka Cipta, Jakarta, 1994.

Fatwa Dewan Syariah Nasional (DSN) Nomor 21/DSNMUI/X/2001 Tentang

Fajar Esya, Jual Beli dalam Perspektif Fiqh.www.ekonomi syariah.org

Gemala Dewi, Aspek - aspek Hukum dalam Perbankan danPerasuransian Syariah di Indonesia, Kencana, Jakarta, 2004. 
- - - - -, Hukum Perikatan Islam di Indonesia, Jakarta, Kencana, 2005.

Man Suparman Sastrawidjaja, Aspek- aspek Hukum Asuransi dan Surat Berharga,PT. Alumni, Bandung, 2003.

Mariam Darus Badrulzaman, Aneka Hukum Bisnis, Allumni, Bandung, 2005.

Muhammad Syakir Sula, Asuransi Syariah (life and General) Gema Insani, Jakarta, 2004.

Peraturan Mahkamah Agung Republik Indonesia Nomor 02 Tahun 2008 Tentang Kompilasi Hukum Ekonomi Syariah

Renny Supriyatni Bachro, Pengantar Perbankan Syariah di Indonesia, Books Terace dan Library,Bandung, 2013.

Ronny Hanitjo Soemitro, Metodologi Penelitian Hukum dan Jurimetri, Ghalia Indonesia, Jakarta, 1990.

Soerjono Soekanto, Pengantar Penelitian Hukum, UI Press, Jakarta, 2008

Sri Redjeki Hartono, Hukum Asuransi dan Perusahaan Asuransi, Sinar Grafika, Jakarta, 1997.

Undang - undang Dasar Negara Republik Indonesia Tahun 1945 Amandemen Keempat Kitab Undang-undang Hukum Perdata

Undang - undang No. 10 Tahun 1998 Tentang Perubahan Atas Undang-undang Nomor 7 Tahun 1992 Tentang Perbankan

Undang - undang Nomor 40 Tahun 2014 Tentang Perasuransian

Wirdyaningsih, Bank dan Asuransi Islam di Indonesia, Kencana, Jakarta, 2005

Zainuddin Ali, Hukum Asuransi Syariah, Sinar Grafika, Jakarta, 2008. 